\title{
Ackee (Blighia sapida) fruit arils: Nutritional, phytochemicals and antioxidant properties
}

\author{
Veronica M. Dossou, Jacob K. Agbenorhevi", Sussana Combey, Sarah Afi-Koryoe \\ Department of Food Science and Technology, Kwame Nkrumah University of Science and Technology, Kumasi, Ghana
}

Email address:

jkagbenorhevi@yahoo.com (J. K. Agbenorhevi),jkagbenorhevi.cos@knust.edu.gh (J. K. Agbenorhevi)

\section{To cite this article:}

Veronica M. Dossou, Jacob K. Agbenorhevi, Sussana Combey, Sarah Afi-Koryoe. Ackee (Blighia sapida) Fruit Arils: Nutritional, Phytochemicals and Antioxidant Properties. International Journal of Nutrition and Food Sciences. Vol. 3, No. 6, 2014, pp. $534-537$. doi: $10.11648 /$ j.ijnfs.20140306.17

\begin{abstract}
The limited information on the health and nutritional benefits of edible arils of the ackee (Blighia sapida) tree makes it underutilized in West Africa. This study was to investigate the nutrient content, total phenols, antioxidant activity and phytochemical constituents of freeze and oven dried ackee arils. Phytochemical analysis was done using standard protocol whereas antioxidant activity and total phenol content was determined using the DPPH and Folin-Ciocalteau methods, respectively. The minerals content was determined by means of atomic absorption spectrophotometry. The moisture, crude fat, crude protein, crude fibre, ash, carbohydrate and energy content were in the range of 4.83-5.20\%, 51.60-56.66\%, 10.94-11.67\%, $3.63-3.88 \%, 8.01-8.56 \%, 14.41-20.62 \%$ and 590.67-614.26 kcal/100g, respectively. The ackee arils also contained appreciable minerals (Ca, P, Mg, Na, K and Zn) with K (425.10-475.71 mg/100g) being the highest while Zn (1.95-2.08 mg/100g) was the least mineral. Phytochemical screening revealed the presence of tannins, saponins and glycosides in the arils. The total phenolic content was $5235.04 \pm 103.9$ and $5175.38 \pm 178.46 \mathrm{mg}$ GAE$/ 100 \mathrm{~g}$ in oven-dried and freeze-dried samples, respectively. The vitamin C content was 29.6 and $35.7 \mathrm{mg} / 100 \mathrm{~g}$ whereas antioxidant activity was 66.0 and $29.4 \%$ DPPH inhibition (with trolox equivalence of $91.0 \pm 9.4$ and $40.6 \pm 0.6 \mu \mathrm{M} \mathrm{TE} / \mathrm{g}$ ) in the oven and freeze dried ackee arils, respectively. Drying method had effect on the phytochemicals and antioxidant activity of the ackee flour sample. The findings suggest that ackee aril had considerable total phenols content and antioxidant activity, which implies that the fruit aril has the potential for application in food systems to maintain food quality.
\end{abstract}

Keywords: Ackee, Ackee Arils, Freeze Dried, Oven Dried, Nutrients, Antioxidants, Phytochemicals

\section{Introduction}

Blighia sapida, commonly known as ackee, is an inherent tree crop of West Africa, prevalent in tropical and subtropical environments. The ripe arils of the ackee fruit, yellow to cream coloured, are nutty-flavored and edible [1]. The arils are the major component of the Jamaican national dish; ackee and saltfish. The ripe fruit arils are eaten fresh, dried, fried, roasted or made into sauce or soup in some parts of West Africa [2].

Ackee arils have been reported to have comparable proximate composition to many known legumes and oil seeds $[1,3,4]$. However, ackee arils have little commercial and nutritional significance in the West African sub-region.

Various parts of the ackee tree are employed in traditional medicine for the treatment of fever, malaria, internal hemorrhage, dysentery, yellow fever, diabetes and constipation in West Africa. The roots, bark, leaves, capsules and seeds were identified in the treatment of 22 diseases in Benin [2]. Consumption of ackee roots bark extract exerted significant hypoglycemic effect on the normoglycemic albino rats [5]. However, limited information exists on the health beneficial components of the arils.

Substantial scientific knowledge on the health beneficial constituents like phytochemicals and antioxidant activity of ackee arils could ensure the development of more efficient ways to convert the fruit into useful products with improved commercial value. This study, therefore, aims to investigate the antioxidant activity, phytochemical constituents, total phenol, vitamin $\mathrm{C}$ content of freeze and oven dried ackee arils. 


\section{Materials and Methods}

\subsection{Source of Materials}

Ackee fruit samples were obtained from Bantama in the Ashanti region of Ghana. Folin-Ciocalteu phenol reagent $(2 \mathrm{~N})$, Trolox ((s)-(-)-6,-hydroxy-2, 5, 7, 8-tetramethyl chroman-2carboxylic acid, $\left.\mathrm{C}_{14} \mathrm{H}_{18} \mathrm{O}_{4}, \quad 97 \%\right)$, Gallic acid $\left(\mathrm{C}_{6} \mathrm{H}_{2}\left(\mathrm{OH}_{3}\right) \mathrm{COOH}\right)$ and 2,2-diphenyl-1-picryhydrazyl (DPPH radical) were purchased from Sigma-Aldrich (Poole, Dorset, UK). All other chemicals used were of analytical grade.

\subsection{Sample Preparation}

Mature ackee fruits were harvested using a sickle. The edible portions were removed from the fruit using knife and divided into two portions. One portion was freeze dried for 72 $\mathrm{h}$ (using a vacuum freeze dryer; YK 115-50, True Ten Industrial Co. Ltd, Taiwan) and the other portion was dried in an oven (Beveilinging Conventional Oven Dryer; DMV 1250, Holland) at $50{ }^{\circ} \mathrm{C}$ for $72 \mathrm{~h}$. The dried sample was milled using an attrition mill and stored in the refrigerator for further analysis.

\subsection{Phytochemical Screening}

The samples were screened for various secondary metabolites. Preliminary phytochemical analysis was carried out to test for the presence of tannins, flavonoids, terpenoids, alkaloids, reducing sugars, saponins and quinones.

The time taken for foam to disappear from samples shaken in distilled water was used to determine the presence of saponins [6]. Glycosides were determined using Fehling's solution I and II and observing for development of a brick-red colour [6]. The presence of tannins was determined using Ferric chloride solution and observing for development of green colour [7]. Deep brown rings and green rings formed after addition of glacial acetic acid followed by concentrated $\mathrm{H}_{2} \mathrm{SO}_{4}$ to sample dissolved in chloroform indicated the presence of steroids and triterpenoids [7]. The Mayer's test as described by Tiwari et al., (2011)[6] was used to determine the presence of alkaloids whereas the alkaline reagent test was used to detect flavonoids [6].

\subsection{Determination of Total Phenol Content}

The total phenol content was analyzed using Folin-Ciocalteu method of measuring the colour change from yellow to blue as a result of reduction of the tungstate-molebdate mixture in the Folin-Ciocalteu reagent by phenols present in the analyte solution [8].

\subsection{Determination of Vitamin C Content}

Vitamin $\mathrm{C}$ was determined using the method of Benderitter et al. (1998) [9].

\subsection{Determination of Antioxidant Activity}

The removal of DPPH by sample was determined using Trolox as standard. Standard calibration of absorbance of
Trolox at $0,50,100,200,500$ and $800 \mu \mathrm{M}$ was employed. The absorbance readings of the DPPH solution at $517 \mathrm{~nm}$ after treatment with sample was subtracted from that of the blank solution and expressed as a percentage.

\subsection{Statistical Analysis}

Results were expressed as mean \pm standard deviation (SD) of three measurements. The Student T-test was used to analyse differences between means, with $p<0.05$ considered to be significant.

\section{Results and Discussion}

\subsection{Nutritional Composition of Ackee Arils}

As shown in Table 1, the moisture contents of both oven and freeze dried ackee arils were low, indicating their potential for long term storage. Ackee arils have high fat content. This oil can be exploited for commercial soap and oil production. However, the low protein content of ackee implies the need for complementing with other protein-rich foods in the diet. The ackee arils also contained appreciable minerals (Ca, P, Mg, Na, K and $\mathrm{Zn}$ ) with $\mathrm{K}(425.10-475.71$ $\mathrm{mg} / 100 \mathrm{~g})$ being the highest while $\mathrm{Zn}(1.95-2.08 \mathrm{mg} / 100 \mathrm{~g})$ was the least mineral determined by atomic absorption spectrophotometry (Table 2).

Table 1. Nutritional Composition of Ackee Arils.

\begin{tabular}{lll}
\hline Parameter & Oven Dried Arils & Freeze Dried Arils \\
\hline Moisture (\%) & $4.83 \pm 0.02 \mathrm{a}$ & $5.20 \pm 0.26 \mathrm{a}$ \\
Fat $(\%)$ & $56.66 \pm 0.27 \mathrm{a}$ & $51.60 \pm 2.23 \mathrm{~b}$ \\
Protein $(\%)$ & $11.67 \pm 0.37 \mathrm{a}$ & $10.94 \pm 0.19 \mathrm{a}$ \\
Ash $(\%)$ & $8.56 \pm 0.44 \mathrm{a}$ & $8.01 \pm 1.13 \mathrm{a}$ \\
Fibre $(\%)$ & $3.88 \pm 0.14 \mathrm{a}$ & $3.63 \pm 0.01 \mathrm{a}$ \\
Carbohydrate $(\%)$ & $14.41 \pm 0.92 \mathrm{a}$ & $20.62 \pm 3.61 \mathrm{~b}$ \\
Energy (kcal/100g) & $614.26 \pm 1.61 \mathrm{a}$ & $590.67 \pm 5.17 \mathrm{~b}$ \\
\hline
\end{tabular}

Table 2. Mineral Composition of Ackee Arils.

\begin{tabular}{lll}
\hline $\begin{array}{l}\text { Mineral } \\
(\mathbf{m g} / \mathbf{1 0 0 g})\end{array}$ & Oven Dried Arils & Freeze Dried Arils \\
\hline $\mathrm{Ca}$ & $160.00 \pm 0.00 \mathrm{a}$ & $200.00 \pm 0.00 \mathrm{~b}$ \\
$\mathrm{Mg}$ & $240.00 \pm 0.00 \mathrm{a}$ & $185.00 \pm 7.07 \mathrm{~b}$ \\
$\mathrm{P}$ & $152.43 \pm 0.00 \mathrm{a}$ & $152.43 \pm 4.15 \mathrm{a}$ \\
$\mathrm{K}$ & $475.71 \pm 0.00 \mathrm{a}$ & $425.10 \pm 14.31 \mathrm{a}$ \\
$\mathrm{Zn}$ & $1.95 \pm 0.05 \mathrm{a}$ & $2.08 \pm 0.02 \mathrm{~b}$ \\
$\mathrm{Na}$ & $84.24 \pm 0.00 \mathrm{a}$ & $73.37 \pm 3.84 \mathrm{a}$ \\
\hline
\end{tabular}

${ }^{\mathrm{a}-\mathrm{b}}$ Values in a row with different letters are significantly different $(\mathrm{p}<0.05)$.

\subsection{Phytochemical Constituents of Ackee Arils}

Table 3 shows the phytochemical constituents of the ackee arils.

Tannins and glycosides were present in both oven and freeze dried arils while saponins were present in oven dried arils only. Flavonoids, triterpenes, cyanogenic and anthracene glycosides as well as alkaloids were absent in both oven and freeze dried arils. Also, negative results were obtained for saponins, flavonoids, triterpenes, anthracene glycosides, cyanogenic glycosides and alkaloids. The absence of these 
phytochemical constituents may be due to ripening and maturation of the fruit as well as exposure to sunlight as suggested by Boyer and Liu, (2004) [10]. Cyanogenic glycoside being absent is a positive indication that the fruit is not toxic since it is an indication of toxicity and poisoning [11]. Thus the ripened ackee arils are non toxic. These results obtained are similar to those obtained by Hamzah et al. (2013) [12] and John-Dewole and Popoola (2013) [13], who confirmed the presence of saponin, saponin glycoside, tannin, balsam and cardiac glycosides and alkaloids, tannins, saponins, flavonoids and phenols, respectively.

Table 3. Phytochemical Constituents of Ackee Arils.

\begin{tabular}{lll}
\hline Phytochemical constituent & Oven-dried Arils & Freeze- dried Arils \\
\hline Saponins & + & - \\
Tannins & + & + \\
Flavonoids & - & - \\
Triterpenes & - & - \\
Glycosides & + & + \\
Cyanogenic glycosides & - & - \\
Anthracene glycosides & - & - \\
Alkaloids & - & - \\
\hline
\end{tabular}

+ Present - Absent

\subsection{Total Phenols, Vitamin C Content and Antioxidant of Ackee Arils}

Generally, oven dried ackee arils expressed higher total phenol content, antioxidant activity and trolox equivalent concentration than freeze dried arils (Table 4). This could be due to the presence of maillard reaction products generated during the oven drying. Maillard reaction products are brown polyphenolic compounds which are known to express some antioxidant activity. Vitamin $\mathrm{C}$ content of oven dried ackee arils was lower than that of freeze dried arils. This was probably due to the degradation of vitamin $\mathrm{C}$ by the application of heat during oven drying. Application of heat causes loss of vitamin C [14]

According to Kaur and Kapoor (2002) [15], antioxidant activity can be classified as low when $\%$ inhibition is $<60 \%$, moderate if $60-70 \%$ and high if $>70 \%$. Hence the antioxidant activity of freeze dried ackee arils can be said to be low while that of oven dried arils is moderate.

Table 4. Total Phenols, Vitamin C Content and Antioxidant Activity of Ackee Arils.

\begin{tabular}{lll}
\hline Composition & Oven-dried Arils & Freeze-dried Arils \\
\hline Total Phenol (mg GAE/100g) & $5235.0 \pm 103.9 \mathrm{a}$ & $5175.4 \pm 178.5 \mathrm{a}$ \\
Vitamin C (mg/100g) & $29.6 \pm 0.4 \mathrm{a}$ & $35.7 \pm 1.3 \mathrm{~b}$ \\
Antioxidant Activity & $66.0 \pm 6.8 \mathrm{a}$ & $29.4 \pm 0.4 \mathrm{~b}$ \\
$\begin{array}{l}\text { (\% DPPH inhibition) } \\
\text { Trolox equivalent }(\mu \mathrm{M} \mathrm{TE} / \mathrm{g})\end{array}$ & $91.0 \pm 9.4 \mathrm{a}$ & $40.6 \pm 0.6 \mathrm{~b}$ \\
\hline
\end{tabular}

${ }^{\mathrm{a}-\mathrm{b}}$ Values in a row with different letters are significantly different $(\mathrm{p}<0.05)$.

In comparison to ackee arils, lower total phenol content (4.64 to $8.90 \mathrm{mg}$ of GAE/g) and Higher \% inhibition (78.5 $88.4 \%$ ) was reported for bitter melon varieties [16]. Carper fruits were, however, reported to have higher total phenol content $(7500 \mathrm{mg} / 100 \mathrm{~g})$ than ackee arils [17]
Ackee arils could serve as an appreciable source of natural antioxidants which could play a key role in health maintenance and prevention of the chronic and degenerative diseases, such as, cardiac and cerebral ischemia, carcinogenesis, neurodegenerative disorders, diabetic pregnancy, rheumatic disorder, DNA damage and ageing [18, 19]. These natural plant phenolics in ackee fruit aril have the potential for application in food systems to maintain food quality.

The vitamin $\mathrm{C}$ content of the ackee arils were lower than that in orange $(50 \mathrm{mg} / 100 \mathrm{~g})$ but higher than that in tomatoes (15 mg/100 g) as reported by Belitz et al. (2009) [20]. Higher vitamin $\mathrm{C}$ content $(65 \mathrm{mg} / 100 \mathrm{~g})$ was reported in fresh ackee arils by Atolani et al. (2009) [21]. Heat generated during processes such as drying and milling could account for the lower vitamin $\mathrm{C}$ content in the oven and freeze dried ackee arils.

The considerable amount of vitamin $\mathrm{C}$ in the ackee arils enables its usage as an antioxidant, thus stabilizing folate in food and in plasma, by increasing excretion of oxidized folate derivatives in human scurvy as well as aiding in metabolism such as tyrosine metabolism. It can also be useful in protecting low-density lipoproteins ex vivo against oxidation and can function similarly in the blood as well [22]. According to Brody (1999) [23], the RDA of vitamin C is $60 \mathrm{mg} / 100 \mathrm{~g}$, therefore consuming about $200 \mathrm{~g}$ of ackee fruit aril can help achieve recommended daily intake of vitamin $\mathrm{C}$.

The high of total phenol content of ackee arils indicate that ackee is a good source of phenols and can be used for reducing blood pressure, lowering of cancer and cardiovascular diseases, for level free radical adsorption and neutralization, as anticancer and antibacterial agents.

The high total phenol content ackee arils is likely due to the presence of ascorbic acid. Other very easily oxidizable substances, not considered as phenolic compounds, may also result in the formation of blue color with Folin-Ciocalteu reagent, causing an overestimation of total phenolic content [24]. Consumption of approximately $1000 \mathrm{mg}$ GAE/day of total phenolic compounds was recommended by Scalbert and Williamson (2000) [25]. Therefore consuming 100g of ackee fruit aril a day can help achieve the normal daily intake of total phenols.

\section{Conclusion}

The results indicate the presence of tannins, saponins and glycosides in the ackee fruit arils. The arils also had considerable total phenols content, minerals, vitamin $\mathrm{C}$ and antioxidant activity. This implies that utilization of ackee arils could impart antioxidant benefits to products and consumers.

\section{References}

[1] Oyeleke, G.O., Oyetade, O.A., Afolabi F. \& Adegoke, B.M. (2013). Nutrients, antinutrients and physicochemical compositions of blighia sapida pulp and pulp oil (ackee apple). Journal of Applied Chemistry, 4(1), 05 - 08. 
[2] Ekué, M .R. M., Sinsin, B., Eyog-Matig, O. \& Finkeldey, R. (2010). Uses, traditional management, perception of variation and preferences in ackee (Blighia sapida K.D. Koenig) fruit traits in Benin: Implications for domestication and conservation. Journal of Ethnobiology and Ethnomedicine, $6(12), 1-14$

[3] Akintayo E. T., Adebayo E. A. \& Arogunde, L. A. (2002). Assessment of dietary exposure to the natural toxin hypoglycin in ackee (Blighia sapida) by Jamaicans. Food Research International, 37, 833-838.

[4] Howélé, O., Bobelé, N., Théodor, D. \& Séraphi, K. C. (2010). Nutritional composition studies of sun dried Blighia sapida (K. Koenig) aril from Côte d'Ivoire. Journal of Applied Biosciences 32, 1989-1994.

[5] Saidu, A. N., Mann, A. and Onuegbu, C. D. (2012), Phytochemical Screening and Hypoglycemic Effect of Aqueous Blighia sapida Root Bark Extract on Normoglycemic Albino Rats, British Journal of Pharmaceutical Research, 2(2): 89 - 97.

[6] [6] Tiwari, P., Kumar, B., Kaur, M., Kaur G, Kaur H: Phytochemical screening and extraction: a Review. Internationale Pharmaceutica Sciencia 2011, 1:98-106

[7] Gowri, S. S. and Vasantha, K. (2010). Phytochemical Screening and Antibacterial Activity of Syzygiumcumini (L.) (Myrtaceae) Leaves Extracts. International Journal of Pharm Tech Research, Vol.2, No.2, pp 1569-1573, ISSN: 0974-4304.

[8] Singleton, V. L. and Rossi J. A. (1965). Colorimetry of total phenolics with phosphomolybdic-phosphotungstic acid reagents. Am J EnolVitic 16:144-158.

[9] Benderitter M., Maupoil V., Vergely C., Dalloz F., Briot F. and Rochettel (1998). Studiesby Electron Paramagnetic Resonance of the Importance of Iron in the Hydroxyl Scavenging Properties of Ascorbic Acid in Plasma; Effects of Iron Chelators.Fundamentals Clin.Pharmacol. Volume12, pp 540-516.

[10] Boyer Jeanelle and Liu Rui Hai, (2004). Apple phytochemicals and their health benefits. Nutrition Journal, 3:5 doi:10.1186/1475-2891-3-5.

[11] Sarker, S.D. and Nahar, L. (2007). Chemistry for Pharmacy Students General, Organic and Natural Product Chemistry. England: John Wiley and Sons. pp 283-359.

[12] Hamzah, R. U., Egwim, E. C., Kabiru, A. Y. and Muazu, M. B. (2013). Phytochemical and in vitro antioxidant properties of the methanolic extract of fruits of Blighia sapida, Vitellaria paradoxa and Vitex doniana. Oxidants and Antioxidants in Medical Science, 2(3), 217-223
[13] John-Dewole, O. O. and Popoola, O. O. (2013).Chemical, Phytochemical and Antimicrobial Screening of Extracts of $B$. sapida for Agricultural and Medicinal Relevance. Nature and science, vol. 11, Issue10, p12-17, 6 .

[14] Fellows, P. J. (2000). Food processing technology; principles and practice, $2^{\text {nd }}$ edn. Woodhead Publishing in Food Science and Technology. pp 238

[15] Kaur, C. and Kapoor H. C. (2002). Antioxidant activity and total phenolic content of some Asian vegetables. International Journal of Food Science and Technology 37, 153-161.

[16] Horax, R., Hettiarachchy, N. and Islam S. (2005). Total Phenolic Contents and Phenolic AcidConstituents in 4 Varieties of Bitter Melons (Momordica charantia) and Antioxidant Activities of their Extracts. Journal of Food Science C275. Vol. 70

[17] Tlili N, Khaldi A, Triki .S and Munné-Bosch S. (2010). Phenolic Compounds and Vitamin Antioxidants of Caper (Capparis spinosa).Plant Foods Hum Nut; 65:260-265.

[18] Uddin, S. N., Akond, M. A., Mubassara, S. and Yesmin M. N. (2008). Antioxidant and Antibacterial activities of Trema cannabina. Middle-East Journal of Scientific Research 3:105108.

[19] Jayasri, M. A., Mathew, L. and Radha, A. (2009). A report on the antioxidant activities of leaves and rhizomes of Costus pictus D. Don. International Journal of Integrative Biology.5(1):20-26.

[20] Atolani, O., Olatunji, G. A. \& Fabiyi, O. A. (2009). Blighia Sapida: The plant and its hypoglycins: an overview. Journal of Scientific Research, XXXIX (2): 15-25

[21] Belitz, H.-D., Grosch, W. and Schieberle, P. (2009). Food Chemistry, 4th revised and extended. Springer-Verlag Berlin Heidelberg. pp 404-407,417.

[22] FAO/WHO (2001). Food and Nutrition Division, FAO, Rome. Report of a joint FAO/WHO expert consultation Bangkok, Thailand Expert Consultationon Human Vitamin and Mineral Requirements. Chapter 6, Page 75-81

[23] Brody, T. (1999). Nutrition Biochemistry. $2^{\text {nd }}$ Edition. Academic press, San Diego - California. Pp 617-620

[24] Shahidi, F. and Naczk, M. (2004). Phenolics in Food and Nutraceuticals, CRC Press, Boca Raton, FL. pp. 489-490.

[25] Scalbert, A. and Williamson, G. (2000). Dietary intake and bioavailability of polyphenols. Journal of Nutrition 130, $2073 S-2085 S$. 